\title{
Method for purification of collagen: A systematic review
}

\author{
Nursyahidatul Azwa Awang ${ }^{a}$, Azura Amid ${ }^{*}$, Zatul Iffah Arshad ${ }^{b}$ \\ International Institute for Halal Research and Training (INHART), Level 3, KICT Building, International Islamic University Malaysia \\ (IIUM), Jalan Gombak, 53100 Kuala Lumpur, Malaysia \\ ${ }^{b}$ Faculty of Chemical Engineering and Natural Resources, Universiti Malaysia Pahang, Lebubraya Tun Razak, 26300 Gambang, Kuantan, \\ Pahang
}

Received 21st January 2020 / Accepted 25th June 2020

\begin{abstract}
Collagen has diverse applications in various industries and thus a various method of purifications has been developed over the years to produce high yield and high purity of collagen to fulfill collagen market demand. The objective of this qualitative systematic review is to summarize the current literature on the existing purification methods for collagen from different sources. Toward this end, three databases were searched and articles were screened for all original articles explaining the purification of collagen regardless of their main sources. After the comprehensive screening, out of 715 articles, 12 articles were chosen and were further reviewed. The analysis of the technical details, theory, advantages, and disadvantages of the techniques used are reported in this study. We found four types of purification methods that commonly used to purify various types of collagen from mammals, marine, bacteria, and recombinant collagen. The correlations between the prevalence of the method and the efficiency of collagen purification were also identified. It highlighted that many factors should be considered before choosing any method of purification such as types, sources and structure of the collagen itself. Affinity chromatography commonly used for purification of recombinant collagen as they have been genetically modified and appended by affinity tags whereas conventional purification method is preferable for nonrecombinant collagen from mammalian and marine sources.
\end{abstract}

Keywords: collagen, purification, ATPS

\section{INTRODUCTION}

Collagen is the most abundant protein in the extracellular matrix of the animal kingdom, including all vertebrates and invertebrates (Fidler et al., 2018; Kadler et al., 2007; Ricard-Blum \& Ruggiero, 2005). About $30 \%$ of total proteins in mammals are represented by collagen. It is a fibrous structural protein that can be identified by containing three polypeptide chains that twisted together in the form of a triple helix structure (Berisio et al., 2002; Hashim et al., 2015; Kittiphattanabawon et al., 2015; Swatschek et al.,

*Author for correspondence: Azura Amid, International Institute for Halal Research and Training (INHART), Level 3, KICT Building, International Islamic University Malaysia (IIUM), Jalan Gombak, 53100 Kuala Lumpur, Malaysia. Email - azuraamid@iium.edu.my
2002; Werkmeister \& Ramshaw, 2015; Yamazaki et al., 2010).

The special characteristic of the structure is the tight packing of the triple helix that requires a small amino acid which is glycine (Gly) to fill the interior axis of the structure. Hence, it leads to the formation of a repetitive sequence pattern (Gly$\mathrm{Xaa}-\mathrm{Yaa}) \mathrm{n}$ for each polypeptide, which is a distinctive feature of collagens (Brodsky \& Ramshaw, 1997; Muyonga et al., 2004). In mammalian collagen, the Xaa and Yaa positions are usually represented by proline and 
hydroxyproline respectively (Werkmeister \& Ramshaw, 2015). Hydroxyproline (Hyp) is the product from the post-translational modification of amino acid proline (Gorres \& Raines, 2010). Figure 1 shows the amino acid structure in collagen molecules (Yamazaki et al., 2010). Collagen plays a crucial role in the human body especially in maintaining elasticity, firmness, and strength to the skin and helps in tissue and organ development. Collagen also protects the skin by inhibiting the absorption of toxins and pathogens (Silvipriya et al., 2015).

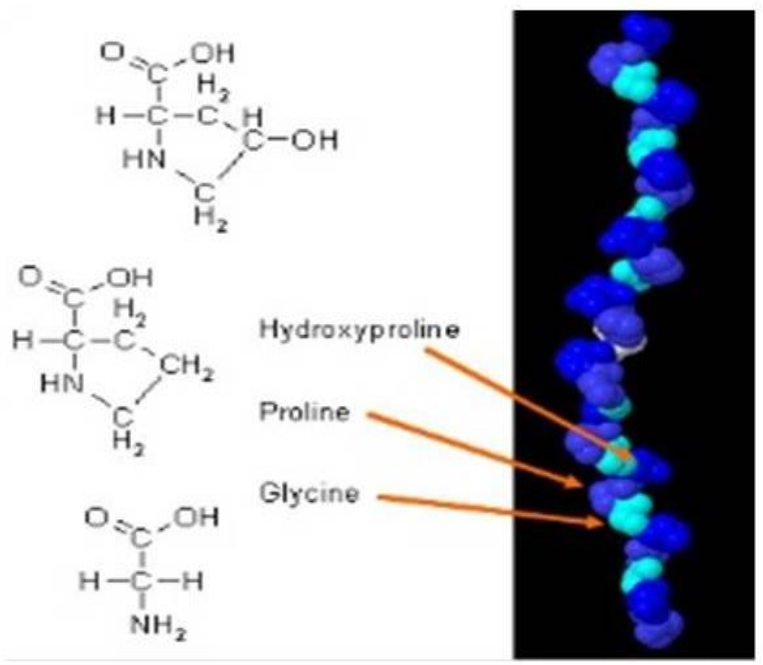

Figure 1. Triple structure helix of collagen (Silvipriya et al., 2015).

In recent years, recovery and purification of proteins are the major challenges due to its complexity and high cost (Stitt \& Weatherley, 1994). Purification process which is the most crucial step and makes up more than $70 \%$ of the downstream processing cost (Alves et al., 2000). The conventional methods consist of several unit operations that lead to a high cost of operation and maintenance (Przybycien et al., 2004; Raja et al., 2012; Song et al., 2013). For instance, precipitation needs to be combined with other processes such as chromatography processes, which are complex, tedious, time-consuming and often produced low yields (Cao \& Xu, 2008; Sato et al., 2003; Wang et al., 2017). Furthermore, the high number of unit operations involved causes a high loss of target molecules that will result in low product yield (Xing et al., 2012).

Applications of collagen emerged in various fields such as pharmaceutical, food, and cosmetic industry. Due to its biodegradability, cell attachment ability, weak antigenicity, and biocompatibility, collagen showed high demand as microparticles, injectable dispersions, shield in ophthalmologysponges, and drug delivery system (Kaufman et al., 1994; Liu et al., 2010; Shin et al., 2016). As humans getting older, the production of collagen getting slower results of losing the human skin elasticity. Thus, the most common ingredient in cosmetics especially in skin care products is collagen. Alike pharmaceutical industry, collagen has great potential in the food industry as a component for texturizing and thickening due to its good water absorption capacity (Felician et al., 2018; Hashim et al., 2015).

The objective of the present review is to summarize and view the current literature on the existing purification methods for collagen from various sources. The advantages and disadvantages of every method were carefully explored and the major outcomes of purification, yield, and purities were discussed.

\section{MATERIALS AND METHODS}

The present methodology is in accordance with the Preferred Reporting Items for Systematic Reviews and Meta-Analyses (PRISMA) statement.

\section{Inclusion process}

The first step on this process was to make extensive literature search in Scopus (http://www.scopus.com/), ScienceDirect (https://www.sciencedirect.com/) and PubMed (https://www.ncbi.nlm.nih.gov/pubmed)

databases that were published up until $9^{\text {th }}$ of May 2019 using the following keywords: (collagen OR recombinant collagen) AND (purification OR isolation OR extraction). The selection of journals in this review emphasized the high impact journals that specialized in a particular field. Papers that did not report the method of purification of collagen, review articles, and articles that were written in foreign languages were excluded. Due to the limited studies on this topic, there were no limitations regarding the year of publication. No restrictions for the method of purification, sources of collagen, type of analysis, and quantification of results. The articles that reported the following data were included: 1) the 
details of purification steps 2) sources of collagen 3) purity or yield of collagen produced.

\section{Variables of interest}

The following data were extracted from the included publications: 1 ) the year of publication 2) sources of the collagen 3) method of purification/extraction 4) advantages of each method 5) disadvantages of each method 6) method of collagen quantification and 7) the product yield.

\section{RESULTS AND DISCUSSION}

\section{Inclusion Process}

The inclusion process is summarized in Figure 2. By using the establishing search procedure and keywords, a total of 526 articles were found in the PubMed database, 84 articles in Science Direct database, and 105 articles in the Scopus database, totaling 715 articles. Of the articles that were identified, 64 were duplicates, 473 were not considered further for inclusion based on abstract screening and 166 articles (Appendix 1) were excluded for not reporting the main outcome of the procedure, as detailed in Figure 1. According to defined inclusion criteria, 12 articles were selected for this review.

\section{Sources of collagen}

Collagen can be extracted from various sources such as land animals, marine animals, and microorganisms. Widespread applications of collagen in cosmetic, biomedical, and pharmaceutical industries make collagen from skin and bones of bovine and porcine collagen as the major industrial sources of collagen (Cliché et al., 1998).

Based on this systematic review 12 articles were selected, of which 5 were carried out using collagen derived from the recombinant system, 4 using collagen from mammalians and 3 described isolation and purification of marine-derived collagen. Two out of five studies reported about collagen-like molecules in bacteria and the rest studies reported about recombinant collagen from animals and non-animal sources.

Recently, instead of focusing on animalderived collagen, most of the studies focused on non-mammalian sources such as bacteria and marine sources. Less than half of the publications reported about the purification of collagen from mammalian sources. This is due to the outbreak of transmissible diseases like bovine spongiform encephalopathy (BSE), transmissible spongiform encephalopathies (TSE) and foot-and-mouth disease (FMD) that pose threat to human (Jongjareonrak et al., 2005; Peng et al., 2012a; Silvipriya et al., 2015; Singh et al., 2011; Swatschek et al., 2002; Zhang et al., 2009). Furthermore, religious sentiments for Muslims, Jewish, and Hindus created another issue in the consumption of porcine or bovine-derived collagen (Sadowska et al., 2003; Singh et al., 2011; Souza, 2016; Wang et al., 2017). Islamic and Jewish believers are prohibited in the consumption of pork, whereas bovine sources are prohibited for Sikhs and Hindus (Eriksson et al., 2013; Herbert et al., 1994; Singh et al., 2011; Souza, 2016). Considering the potential shortcomings and religious sentiments related to mammalian collagen and marine collagen can be seen as a promising alternative to mammalian collagen since they are free from zoonosis, lees immunogenic, high content of collagen, and environmental friendly (Silva et al., 2014; Silvipriya et al., 2015) (Felician et al., 2018)(Applications et al., 2019). Marine based collagen can be extracted from marine sponges (Swatschek et al., 2002), jellyfish (Krishnan \& Perumal, 2013), squid (Raman \& Mathew, 2014), and fish (Kiew \& Don, 2013) and their offal including processing waste such as fish skin, scales, bones, fins, and heads (Maya Raman \& Gopakumar, 2018; Sadowska et al., 2003). Thus, these under-utilized sources can be considered as sustainable and cost-effective(Maya Raman \& K Gopakumar, 2018; Senaratne et al., 2006).

Nowadays, collagen-like molecules from bacteria have become the attention of researchers and scientists to find another alternative of animal-derived collagen (An et al., 2014; Peng et al., 2012a; Xu et al., 2010, 2014). Collagen proteins from Methylobacterium sp. 446, Rhodopseudomonas palustris, and Solibacter usitatus were identified as soluble proteins whereas collagen from Clostridium perfringens was found as inclusion bodies (Xu et al., 2010). Interestingly, bacterial collagen can form a triple helix structure through electrostatic interactions and functioned as animal collagen even though they are lacking of post- 
translationally modified amino acid, hyroxyproline (Hyp) ) (Peng et al., 2012b). With the absence of hyp, they were stable around mammalian body temperature, with melting temperatures of $36.4^{\circ} \mathrm{C}$ and $37.6^{\circ} \mathrm{C}$ (Ramshaw et al., 2014; $\mathrm{Xu}$ et al., 2002). Hydroxyproline is responsible in stabilize the triple helix structure of collagen (Berisio et al., 2002). If the stability of collagen is low, collagen will be denatured and stay in single-chain without folding into the native triple-helical structure. This single structure is known as gelatin (Ramshaw et al., 2014). Out of these 12 articles, only 2 describing bacterial collagen, clearly indicating a need for further research related to bacterial collagen.

Figure 2. Flow diagram of the inclusion process.

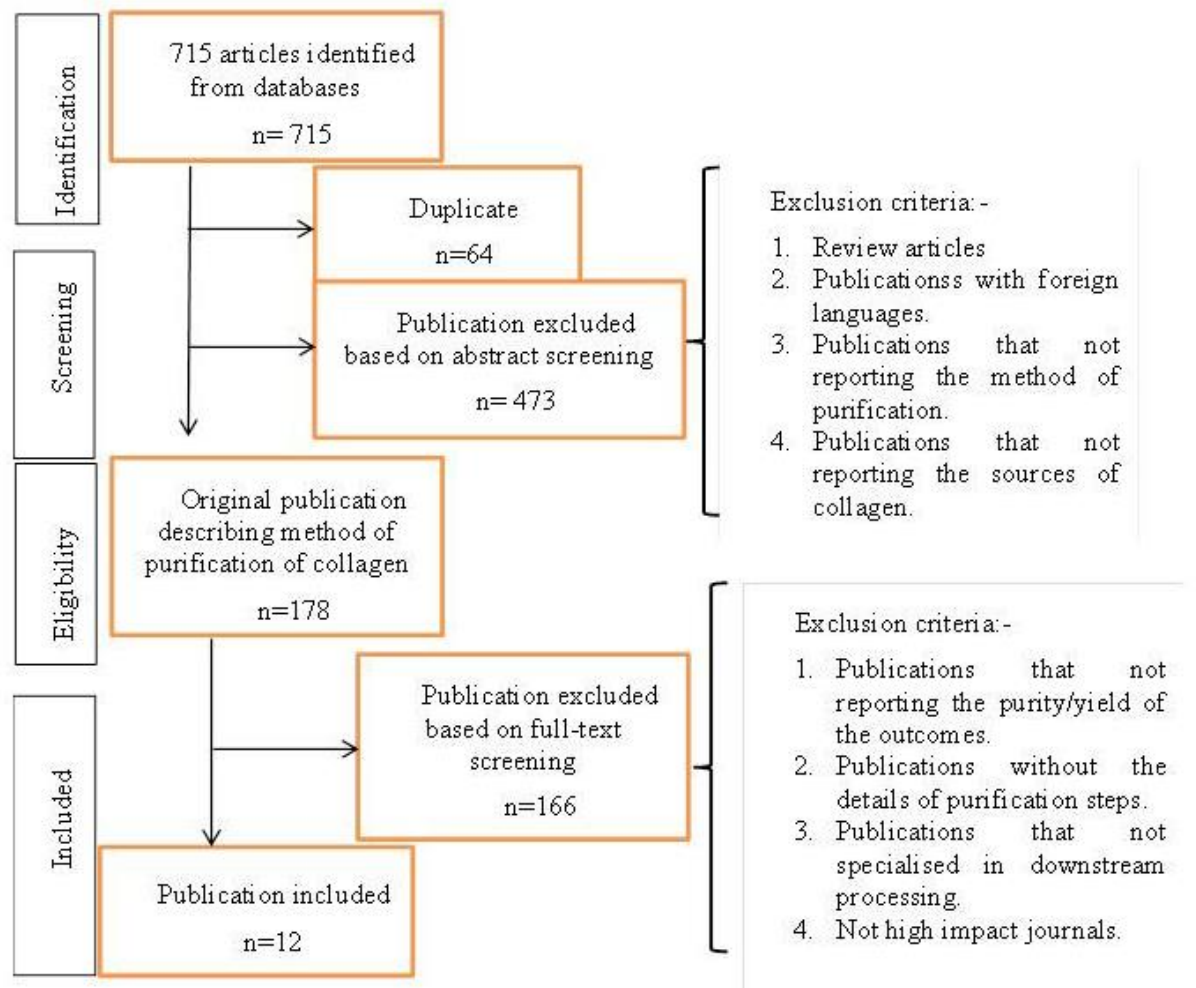

\section{Purification of collagen}

There are many techniques on the purification of collagen has been invented for the past years. The conventional purification methods for collagen are precipitation, filtration, and chromatography (Mazzola et al., 2008).

\section{Affinity chromatography}

It has been stated that over $60 \%$ of all purification techniques involve affinity chromatography (Magdeldin \& Moser, 1996; Przybycien et al., 2004). The principle behind this technique is based on the reversible interactions between the desired protein and affinity ligand coupled to the chromatographic matrix (Magdeldin \& Moser, 1996; Pontis, 2017; Urh et al., 2009). During this process, the specific protein will bind to the ligand while non-bound components leave the column before the elution process occurred by altering the buffer conditions (Coskun, 2016). Next, the bounded molecule will be eluted during the desorption step by altering conditions leading to the binding such as $\mathrm{pH}$ or salt concentration (Fujita-Yamaguchi, 2015). The target protein will be collected in a concentrated form.

Purification of collagen using affinity chromatography was reported in 3 out of 12 studies (25\%) (Rutschmann et al., 2013; Warner et al., 2007; Xu et al., 2010). These studies involved the purification of different types of collagen from recombinant system technology. There are several types of columns available for the application of affinity chromatography such as zinc, cobalt, copper, and nickel (Magdeldin \& Moser, 1996). Those studies used the nickel affinity column for their purification process. One publication reported the procedure of affinity chromatography using a fast protein liquid chromatography (FPLC) system, and sepharose as the chromatographic matrix (Rutschmann et al., 
2013). Sepharose is a registered tradename for a cross-linked agarose-based, beaded-form gel matrix (Zucca et al., 2016). FPLC previously known as fast performance liquid chromatography is a medium pressure chromatography that mainly used for purification of proteins and biomolecules. Its stationary phase is composed of small diameter beads which make it different from HPLC (Pontis, 2017). Compared to high-performance liquid chromatography (HPLC), the cost per test for FPLC is 30 times cheaper whereas its column is 10 times cheaper than HPLC column (Gireesh, 2004; Tangvarasittichai et al., 2009). However, the yield of collagen produced using this method is very low which is about $0.009 \%$.

According to $\mathrm{Xu}$ et al. (2010) and Warner et al. (2007), agarose was chosen as the chromatographic matrix for their studies due to its ability to form a highly porous matrix with minimal non-specific adsorption. Agarose is a polysaccharide that originated from seaweeds that able to form spontaneous gelation (Aschenbrenner et al., 2013; Royhaila et al., 2015; Zucca et al., 2016). His-tagged proteins were purified by affinity chromatography Ni-NTA agarose superflow column (Warner et al., 2007; Xu et al., 2010). The expression of histidine-tag recombinant protein allows it to be selectively bound by divalent metal ions (Bolanos-garcia \& Davies, 2006; Hochuli et al., 1987; Smith et al., 1988). Then, a high concentration of imidazole was used in the desorption step as an elution buffer to elute the target protein (FujitaYamaguchi, 2015; Rutschmann et al., 2013; Warner et al., 2007; Xu et al., 2010). The recovery of collagen is about $11 \%$ to $12 \%$ (Xu et al., 2010) and 15\% (Warner et al., 2007).

Affinity chromatography is most preferable due to its high resolution and high selectivity (Bolanos-garcia \& Davies, 2006; Pontis, 2017). All the publications reported the affinity chromatography technique used is immobilized metal affinity chromatography (IMAC) technique and nickel as the immobilized metal ion on the matric because it gives high yield compared to other types of column (Bolanos-garcia \& Davies, 2006; Bornhorst \& Falke, 2000). This technique is widely used especially for the single-step purification of recombinant proteins (Block et al., 2009). Affinity- tagged protein purities can be achieved in high yield at up to $95 \%$ purity by IMAC (Bryntesson et al., 2011). However, proteins from E. coli host sometimes naturally binds to the nickel ligand and co-eluted with the recombinant protein during the purification process. This problem usually solved by applying a high concentration of imidazole. Protein that was observed to be co-purified with the Histagged protein can be divided into four groups (Bolanos-garcia \& Davies, 2006):

I. proteins with natural metal-binding motifs

II. proteins with histidines clusters on their surfaces

III. proteins that bind to heterologously express His-tagged proteins

IV. protein with affinity to agarose-based supports

As we know, tagged protein has a higher binding affinity than other proteins that bind nonspecifically to the resin. The filtered binding buffer used contained a low concentration of imidazole. Imidazole is a chemical that is very specific to nickel. When the minimum amount of resin used, the tagged protein will fill most of the available binding sites and will decrease the nonspecific binding. Conversely, a high concentration of imidazole was used in the elution buffer. The main function of imidazole is to reduce the nonspecific binding of a protein to the column. It will compete with the polyhistidine-tagged to the recombinant protein for binding to the column and the purified protein will be eluted out from the column.

Even though affinity chromatography is the most promising method especially for recombinant collagen, there are still serious issues. For example, Block and co-workers reported that the complexity of its procedures and the high cost of maintenance due to the multiple stages involved are viewed as significant disadvantages (Coskun, 2016). Besides, how the affinity tags used may alter the protein activity is a growing concern (Bornhorst et al., 2000; Dimitrova et al., 2017). Proteins with a low level of expressions will not able to incorporate with this method and they require other affinity tags of polyhistidine tag with additional purification techniques (Bornhorst et al., 2000). It is undeniable that this method comes first in the purification of recombinant proteins, 
however, it is lacking in terms of productivity and economical value and thus not sustainable for large scale and long-term production.

\section{Ion exchange chromatography}

Ion-exchange chromatography works based on electrostatic interactions between charged protein groups, and solid support material (matrix). There are two types of resins which are cation and anion exchange. Negatively charged proteins will bind to positively charged ion-exchanged matrices and vice versa (Dimitrova et al., 2017). According to Sato and co-workers, filter paper-based Diethyl aminoethyl cellulose (FBP DEAE) column chromatography was used to purify type $\mathrm{V}$ collagen from a pepsin digest of porcine intestinal connective tissue (Sato et al., 2003).

One out of twelve $(8.3 \%)$ of the selected articles reported using ion-exchange chromatography as the method of collagen purification (Sato et al., 2003). Filter paper-based Diethyl aminoethyl cellulose (FBP DEAD) column chromatography is an example of ionexchange chromatography used to purify type $\mathrm{V}$ collagen from the porcine intestine (Sato et al., 2003).

Examples of ion exchanger matrix used in this technique are dextran, polystyrene, cellulose, and acrylic (Coskun, 2016). The introduction of FPB DEAD-cellulose by Sato and co-workers allowed the purification of type $\mathrm{V}$ collagen using a rapid and simple way with high yield in a shorter time (Sato et al., 2003). Besides the charge, the $\mathrm{pH}$ of the binding buffer also plays an important role in this technique. For a successful binding, the $\mathrm{pH}$ value must below the isoelectric point $(\mathrm{pI})$ of the protein (Dimitrova et al., 2017). According to Henderson-Hasselbalch principle, if the $\mathrm{pH}$ of the binding buffer is merely one $\mathrm{pH}$ unit below the isoelectric point $(\mathrm{pI})$ of the recombinant proteins, most of the latter will bind to the column (Radic \& Prkic, 2012). In the publication reported by Sato and co-workers, $50 \mathrm{mM}$ Tris-HCl buffer at $\mathrm{pH} 8.20$ was used which is below the isoelectric point (pI) of collagen, 8.26. Instead of improving the specific binding, further decreasing the $\mathrm{pH}$ of the buffer will invite the contaminating proteins to bind (Dimitrova et al., 2017).

According to Sato and co-workers, this technique is able to separate the proteins with high concentration without involving clogging problems. Furthermore, utilization of FPB DEAE-cellulose can be considered as a costeffective method as it is reusable and can be prepared inexpensively using available glassware and reagent such as sodium hydroxide, hydrogen chloride, sodium chloride and 2chlorotriethylamine (Sato et al., 2003). However, the preparation of the experiment is tedious and high possibility of contamination to occur. Examples of contamination that commonly occurred are organic and bacterial contamination from the resin (sciencing) (Block et al., 2009). Same goes to affinity chromatography, along with its ability to produce high purity of the product, ion exchange chromatography is a costly and tedious technique that require expensive chemicals and equipment. Hence, a simple yet efficient technique should be a better choice.

\section{Precipitation}

Precipitation is one of the conventional methods of purification that is widely used in the downstream processing of biomolecules. Precipitation techniques that commonly used in collagen purification are salt precipitation and acid precipitation. Despite its tedious procedures, this method is still applicable in the industry as it is inexpensive compared to other methods.

Three out of $12(25 \%)$ studies used precipitation technique in their procedure. Two out of three publications reported on acid precipitation (Singh et al., 2011; Werkmeister \& Ramshaw, 2015) and the rest conducted the collagen purification using salt precipitation (CaO $\& \mathrm{Xu}, 2008)$. These methods required additional purification processes such as chromatography and pepsin digestion.

Purification of recombinant bacterial collagen using a combination of precipitation and proteolysis by pepsin was performed in two out of three studies (Cao \& Xu, 2008; Werkmeister \& Ramshaw, 2015). Werkmeister, Singh, and coworkers reported that the application of precipitation and proteolysis is applicable to a wide range of bacterial collagen with different collagen domain sizes (Singh et al., 2011; Wang et al., 2017). The acid precipitation method can be considered as an efficient technique in removing a high amount of bacterial host proteins and they will tend to precipitate upon the addition of acid as host proteins were least soluble at a $\mathrm{pH}$ lower 
than 5 (Kiew \& Don, 2013; Werkmeister \& Ramshaw, 2015). However, the significant drawback is the acidic conditions itself may lead to adverse effects on the stability of the triple helix in these bacterial proteins (Werkmeister \& Ramshaw, 2015).

The formation of contaminants alongside the salting-out process is the major challenge in salt precipitation. According to $\mathrm{CaO} \& \mathrm{Xu}, \mathrm{a}$ combination of pepsin digestion, salt precipitation by $\mathrm{NaCl}$, and ion-exchange chromatography were used to purify type II collagen from chick sternal cartilage (Cao \& Xu, 2008). Thus, additional purification process such as chromatography is needed to obtain a high purity protein. Moreover, the involvement of pepsin in the precipitation process will indirectly lead to a high cost of operation due to the high cost of enzymes. Even though precipitation is an easy and inexpensive method, it did not gain in popularity due to its main weakness in producing low purity of proteins. An improvement regarding this method is needed to compete with other purification methods.

\section{Aqueous two-phase system}

Aqueous two-phase system (ATPS) or aqueous biphasic system (ABS) is a liquid-liquid fractionation technique and has been used for many years in biotechnological applications specifically for separation and purification of biological materials such as proteins, enzymes, nucleic acids, virus, antibodies and cell organelles (Iqbal et al., 2016; et al., 2011). ATPS is formed when two aqueous phase consists of two watersoluble polymers or a polymer and a salt that are mixed at appropriate concentrations (Grilo et al., 2014; Raja et al., 2012; Rito-palomares et al., 2014; Song et al., 2013). Then, the mixture will result in two liquid layers with a high content of water (Tjerneld, 1994). In 2002, a new ATPS system has been applied in the purification of glycyrrhizin from Glycyrrbiza uralensis Fisch using alcohol and salt instead of polymer and salt system (Tianwei et al., 2002).

Prior to this purification process, a unique diagram known as a phase diagram under a specific condition of $\mathrm{pH}$, temperature, or salt concentration needs to be constructed. It is a crucial diagram that provides the information about the concentration of phase-forming components and consists of a binodal curve that separates the region with the biphasic solution (above the curve) from the one that does not (below the curve) (Hatti-Kaul, 2000; Iqbal et al., 2016; Johansson et al., 2011; Raja et al., 2012; Silva et al., 2014; Stitt \& Weatherley, 1994; Tjerneld, 1994). Protein partition in ATPS is a complex phenomenon due to the involvement of many factors including the molecular weight of polymers, and electrochemical and ionic properties of the phases (Iqbal et al., 2016; Jankowski, 2012; Mazzola et al., 2008; Ratanapongleka, 2013; Creighton et al., 1989). The main goal is to localize the target protein in one phase either top or bottom phase and the partition coefficient at each phase will be used to evaluate the purification efficiency (Singh \& Tavana, 2018).

Purification of collagen using the aqueous two-phase system was reported in 1 out of 12 $(8.3 \%)$ studies. The system composed of nonionic polymers polyethylene glycol (PEG) and dextran (DEX) to purify type I rat tail collagen. Table 1 shows 4 types of ATPS system (A, B, C, D) that has been tested in this study. PEG and DEX are the most commonly used in ATPSs among polymers since they can perform desirable physical properties with non-toxicity and applicable for microbial cells due to its stabilizing effect (Ratanapongleka, 2013). Collagen partition is highly sensitive to the molecular weight of polymer which is the factor that can affect the partition of biomolecules (Singh \& Tavana, 2018).

Table 1. Aqueous two-phase system used in collagen partition (Singh \& Tavana, 2018).

\begin{tabular}{ccc}
\hline System & $\begin{array}{c}\text { Polyethylene } \\
\text { Glycol (PEG) }\end{array}$ & $\begin{array}{c}\text { Dextran } \\
\text { (DEX) }\end{array}$ \\
\hline A & PEG8000 & DEX40000 \\
B & PEG8000 & DEX500000 \\
C & PEG35000 & DEX40000 \\
D & PEG35000 & DEX500000 \\
\hline
\end{tabular}


Table 2. Characteristics of included publications regarding purification of collagen.

\begin{tabular}{|c|c|c|c|c|c|}
\hline Reference & Sources of collagen & Method & Advantages & Disadvantages & Yield \\
\hline (Sato et al., 2003) & $\begin{array}{l}\text { Porcine intestine (type } \\
\text { V collagen) }\end{array}$ & $\begin{array}{l}\text { Filter-based paper } \\
\text { DEAD -cellulose } \\
\text { column } \\
\text { chromatography } \\
\text { (ion-exchange } \\
\text { chromatography) }\end{array}$ & - inexpensive & $\begin{array}{l}\text { - } \text { column } \\
\text { chromatography need } \\
\text { to be prepared } \\
\text { manually }\end{array}$ & Qualitative \\
\hline $\begin{array}{l}\text { (Werkmeister \& } \\
\text { Ramshaw, 2015) }\end{array}$ & $\begin{array}{l}\text { Recombinant non- } \\
\text { animals collagen }\end{array}$ & $\begin{array}{l}\text { 1. Acid precipitation } \\
\text { 2. Proteolysis (pepsin) }\end{array}$ & $\begin{array}{l}\text { - Simple and effective } \\
\text { - Inexpensive } \\
\text { - Easy to scale up }\end{array}$ & $\begin{array}{l}\text { - Acidic condition can } \\
\text { affect the stability of } \\
\text { collagen-triple helix } \\
\text { structure } \\
\text { - Further polishing steps } \\
\text { needed for biomedical } \\
\text { application } \\
\end{array}$ & Qualitative \\
\hline $\begin{array}{l}\text { (Rutschmann et } \\
\text { al., 2013) }\end{array}$ & Human collagen & $\begin{array}{l}\text { Affinity } \\
\text { chromatography }\end{array}$ & $\begin{array}{l}\text { - High selectivity } \\
\text { - High purity }\end{array}$ & $\begin{array}{l}\text { - Expensive } \\
\text { - Low yield }\end{array}$ & $\begin{array}{l}\text { Quantitative \& } \\
\text { Qualitative } \\
\text { Yield }=0.009 \% \\
\end{array}$ \\
\hline $\begin{array}{l}\text { (Warner et al., } \\
\text { 2007) }\end{array}$ & Recombinant & $\begin{array}{l}\text { Nickel affinity } \\
\text { chromatography }\end{array}$ & $\begin{array}{l}\text { - High selectivity } \\
\text { - Reduce the risk of } \\
\text { cross-contamination } \\
\text { (prepacked column) }\end{array}$ & $\begin{array}{l}\text { - Low recovery } \\
\text { - Expensive } \\
\text { - Complex to sale up }\end{array}$ & $\begin{array}{l}\text { Quantitative } \\
\text { Yield }=15 \%\end{array}$ \\
\hline (Glatz, 2009) & $\begin{array}{l}\text { Corn grain-derived } \\
\text { recombinant collagen }\end{array}$ & \begin{tabular}{|l} 
1. Membrane \\
ultrafiltration \\
2. Chromatography (4 \\
steps) (IEC)
\end{tabular} & - High yield and purity & $\begin{array}{l}\text { - Pore blockage problem } \\
\text { - Complex process }\end{array}$ & $\begin{array}{l}\text { Quantitative } \\
\text { Yield }=16 \%\end{array}$ \\
\hline $\begin{array}{l}\text { (Singh \& } \\
\text { Tavana, 2018) }\end{array}$ & $\begin{array}{l}\text { Rat tail collagen : Type } \\
\text { I }\end{array}$ & $\begin{array}{l}\text { Aqueous two-phase } \\
\text { system }\end{array}$ & $\begin{array}{l}\text { - Simple and benign } \\
\text { - Cost-effective } \\
\text { - Rapid separation }\end{array}$ & $\begin{array}{l}\text { - Not easy to scale up } \\
\text { because PEG can } \\
\text { cause corrosion of } \\
\text { equipment }\end{array}$ & $\begin{array}{l}\text { Quantitative } \\
\text { Sys A: } 62 \% \\
\text { Sys B: } 34 \% \\
\text { Sys C \& D :58\% }\end{array}$ \\
\hline
\end{tabular}




\begin{tabular}{|c|c|c|c|c|c|}
\hline (Xu et al., 2010) & Recombinant Bacteria & $\begin{array}{l}\text { Affinity } \\
\text { chromatography }\end{array}$ & - High selectivity & $\begin{array}{l}\text { - Expensive } \\
\text { - Low recovery }\end{array}$ & $\begin{array}{l}\text { Quantitative \& } \\
\text { Qualitative } \\
\text { Yield: } 11-12 \%\end{array}$ \\
\hline (Yd et al., 2013) & $\begin{array}{l}\text { Sea cucumber } \\
\text { (Bohadschia bivitatta) }\end{array}$ & $\begin{array}{l}\text { Pepsin-solubilized } \\
\text { collagen (PSC) }\end{array}$ & $\begin{array}{l}\text { - High yield compared } \\
\text { to acid precipitation }\end{array}$ & - Religious sentiments & $\begin{array}{l}\text { Quantitative } \\
\text { Yield }=65 \%\end{array}$ \\
\hline $\begin{array}{l}\text { (Jiang et al., } \\
\text { 2009) }\end{array}$ & Jellyfish & Ultrafiltration & $\begin{array}{l}\text { - Eco- friendly } \\
\text { - Energy saving } \\
\text { - Low maintenance } \\
\end{array}$ & - Low yield/recovery & $\begin{array}{l}\text { Quantitative } \\
\text { Yield }=4.2 \%\end{array}$ \\
\hline $\begin{array}{l}\text { (Cao \& Xu, } \\
2008)\end{array}$ & Cartilage of chick & $\begin{array}{l}\text { - pepsin digestion } \\
\text { - } \mathrm{NaCl} \text { precipitation } \\
\text { - Ion exchange } \\
\text { chromatography }\end{array}$ & - High purity & - Time-consuming & Qualitative \\
\hline $\begin{array}{l}\text { (Singh et al., } \\
\text { 2011) }\end{array}$ & $\begin{array}{l}\text { skin of striped catfish } \\
\text { (Pangasianodon } \\
\text { bypophthalmus) }\end{array}$ & $\begin{array}{l}\text { - Acid Precipitation } \\
\text { - Porcine pepsin }\end{array}$ & $\begin{array}{l}\text { - No effect on triple } \\
\text { helix structure }\end{array}$ & $\begin{array}{lr}\text { Collagen } & \text { not } \\
\text { completely } & \text { solubilized } \\
\text { in acid } & \end{array}$ & $\begin{array}{l}\text { Qualitative and } \\
\text { Quantitative } \\
\text { ASC: } 5.1 \% \\
\text { PSC: } 7.7 \%\end{array}$ \\
\hline
\end{tabular}

DEAD, diethylamino ethyl: IEC, ion-exchange chromatography: ASC, acid-solubilized collagen: PSC, pepsin-solubilized collagen: PEG, polyethylene glycol. 
Although PEG and DEX system are commonly used, the high cost of fractionated dextran is a limitation for its application in a large scale process(Ratanapongleka, 2013). Another system that composed of one polymer and low molecular weight of salt is usually preferred especially in large scale operation due to the low cost of salt compared to dextran (Ratanapongleka, 2013; Rito-Palomares, 2004). Furthermore, the polymer-salt system provides larger differences in density, lower viscosity, and greater selectivity (Ratanapongleka, 2013; Song et al., 2013). However, in terms of the economical aspect, the salt/alcohol system comes first due to the easy recovery of alcohol using the evaporation method (Tianwei et al., 2002). According to data from Table 2, the yield of collagen extracted using this technique is quite high which is $62 \%$ for system A, 34\% for system B, and 58\% for system C and D (Singh \& Tavana, 2018). There are many advantages of aqueous-two phase system which are simple, benign, easy to scale up with rapid mass transfer and excellent separation with little denaturation that make it as a promising substitute for the existing method which is expensive and classical, such as chromatography (Asenjo \& Andrews, 2012; Azevedo et al., 2007; Sarubbo et al., 2004; Silva et al., 2014; Song et al., 2013). Furthermore, they are preferable in biomedical research studies due to its biocompatibility and eco-friendly because they are free from any organic components (Brunette \& Till, 1971; Ling et al., 2010; Song et al., 2013).

The phase separation process only needs one step which is the centrifugation step. A direct comparison between ion-exchange chromatography and aqueous two-phase techniques has been conducted by RitoPalomares, proved that ATPS method able to reduce the number of unit operation (from 7 to 4 ) thus leads to further reduction of the cost by $43 \%$ (Rito-Palomares, 2004).

However, the main disadvantage of this method is the lack of knowledge on the mechanism involved in the partitioning process and poor understanding of the technique (RitoPalomares, 2004). Besides, environmental issues such as salt disposal and their impact on wastewater treatment remain the problem on large scale ATPS process (Ratanapongleka, 2013). Although simple and economical, ATPS has yet to see widespread of collagen purification. In my opinion, if the mechanisms of protein partitioning are deeply studied and understand, ATPS can be a good alternative for large scale protein purification especially collagen.

\section{Ultrafiltration}

The basic understanding of this method is the removal of contaminants by passing the sample through a permeable medium but traps the contaminants or solid particles (Shon et al., 2011). This method of purification is widely used in a water treatment plant in the environmental industry. It is commonly used as a preconcentration step in the purification of protein solutions (Machado et al., 2018; van Reis \& Zydney, 2007). Several research studies have applied this approach include fractionation of whey protein (Cheang \& Zydney, 2004), purification of DNA (Kahn et al., 2000), and lysozyme (Ghosh \& Gui, 2000). However, few studies reporting about collagen purification using the ultrafiltration method (Cao \& Xu, 2008; Jiang et al., 2009).

Purification of collagen using the filtration method has been outlined in 2 out of $12(16.7 \%)$ publications. A membrane made up of polyacrylonitrile (PAN) and hydrophilically modified polyacrylonitrile was used to purify the collagen from jellyfish (Jiang et al., 2009). The utilization of hydrophobic material alone like polyacrylonitrile is problematic due to the rapid fouling during the separation process (Minnesota Rural Water Association, 2001), (Ramli et al., 2014). Hence, hydrophilic and charged membranes are the solutions discovered in recent years to avoid membrane fouling.

Glatz (2009), outlined the purification of corn-grain derived recombinant collagen using a combination of membrane ultrafiltration, nonaffinity chromatography, and low $\mathrm{pH}$ extraction. Polyethersulfone membranes with 30, 50, and 100 $\mathrm{kDa}$ molecular weight cut off (MWCO) were used in the procedures to identify the most potent membrane (Glatz, 2009). The $50 \mathrm{kDa}$ membrane was found to be the most effective membrane with higher flux and shorter processing time that contributed to about $80 \%$ removal of contaminating proteins (Glatz, 2009).

Ultrafiltration is known as an energy-saving and eco-friendly technique that able to produce 
high product throughput compared to other conventional separation methods (Jiang et al., 2009). However, the utmost difficulty in ultrafiltration is membrane fouling that will affect membrane performance and leads to the high cost of maintenance (Aimar \& Bacchin, 2010; Ramli et al., 2014; Tang et al., 2011). Mechanisms of membrane fouling consist of physical and chemical adsorption, precipitation of salts, and the deposition of biofilms and suspended matter onto or into the membrane (Akhondi et al., 2017). Other than that, cross-contamination is a most likely problem occurred in concentration equipment such as stirred ultrafiltration cells with ultrafiltration membranes (Lingala \& Ghany, 2016). Furthermore, this method is not suitable for the separation of low molecular weight species (Tang et al., 2011). Despite these circumstances, ultrafiltration still possess great potential in the purification process especially in the water treatment industry and biotechnology industries such as in protein fractionation (Machado et al., 2018).

About $4.2 \%$ of collagen produced by a study carried out by Jiang and co-workers, which is relatively low (Jiang et al., 2009). Meanwhile 16\% of collagen able to be purified using a combination of ultrafiltration with non-affinity chromatography and low $\mathrm{pH}$ extraction method. Therefore, an additional purification step is needed in this case to obtain a pure and high yield of proteins. For collagen purification, ultrafiltration is not a suitable choice, possibly because of its multi-stages operation to purify the protein from a complex mixture.

\section{CONCLUSION}

In conclusion, many different techniques have been discovered for the purification of collagen. The choice of the purification method mainly relied on the sources, types, and structure of the collagen itself. For instance, affinity chromatography commonly used for purification of recombinant collagen as it has been genetically modified and appended by affinity tags. Meanwhile, the conventional purification method is preferable for non-recombinant collagen from mammalian and marine sources. Notably, out of
12 publications reporting collagen purification, purities and yield were not quantitatively measured in 3 publications. Reporting the yield is very important that will lead to a meaningful interpretation of the results. Furthermore, the cost of analysis of each method used was not reported in any publication. From economic point of view, adding cost analysis could be a good improvement in publishing journals regarding the purification technique.

\section{ACKNOWLEDGEMENTS}

The authors are grateful to the Ministry of Education, for providing the Transdisciplinary Grant (TRGS/1/2018/UIAM/01/1/1) to carry out the study.

\section{REFERENCES}

Aimar, P., \& Bacchin, P. 2010. Slow colloidal aggregation and membrane fouling. Journal of Membrane Science 360(1-2): 70 76.

Akhondi, E., Zamani, F., Tng, K., Leslie, G., Krantz, W., Fane, A., \& Chew, J. 2017. The performance and fouling control of submerged hollow fiber (HF) systems: A review. Applied Sciences 7(8): 765

Alves, J. G. L. F., Chumpitaz, L. D. A., Da Silva, L. H. M., Franco, T. T., \& Meirelles, A. J. A. 2000. Partitioning of whey proteins, bovine serum albumin and porcine insulin in aqueous two-phase systems. Journal of Chromatography $B$ : Biomedical Sciences and Applications 743(1-2): 235-239.

An, B., Kaplan, D. L., \& Brodsky, B. 2014. Engineered recombinant bacterial collagen as an alternative collagenbased biomaterial for tissue engineering. Frontiers in Chemistry 2(40): 1-5.

Arshad, Z. I. M., Amid, A., Yusof, F., Sulaiman, S. Z., Mudalip, S. K. A., Man, R. C., \& Shaarani, S. M. 2017. Perbandingan kaedah penulenan rekombinan bromelain daripada Escherichia coli BL21-A1. Malaysian Journal of Analytical Sciences 21(4): 958-971.

Aschenbrenner, E., Bley, K., Koynov, K., Makowski, M., Kappl, M., Landfester, K., \& Weiss, C. K. 2013. Using the polymeric ouzo effect for the preparation of polysaccharide-based nanoparticles. American Chemical Society 29: 8845-8855.

Asenjo, J. A., \& Andrews, B. A. 2012. Aqueous two-phase systems for protein separation: Phase separation and applications . Journal of Chromatography A 1238: 1-10.

Azevedo, A. M., Rosa, P. A. J., Ferreira, I. F., \& Aires-Barros, M. R. 2007. Optimisation of aqueous two-phase extraction of human antibodies. Journal of Biotechnology 132(2): 209-217.

Berisio, R., Vitagliano, L., Mazzarella, L., \& Zagari, A. 2002. Crystal structure of the collagen triple helix model [(Pro-ProGly)10]3. Protein Science 11: 262-270.

Block, H., Maertens, B., Spriestersbach, A., Brinker, N., Kubicek, 
J., \& Fabis, R. 2009. Immobilized-metal affinity chromatography (IMAC ): A review. Methods in Ensymology 463(09): 439-473

Bolanos-garcia, V. M., \& Davies, O. R. 2006. Structural analysis and classification of native proteins from $E$. coli commonly co-purified by immobilised metal affinity chromatography. Biochimica et Biophysica Acta 1760: 1304-1313.

Bornhorst J.A., \& J.J., F. 2000. Purification of proteins using polyhistidine affinity tags. Methods in Ensymology 326(1): 245-254.

Brodsky, B., \& Ramshaw, J. A. M. 1997. The collagen triple-helix structure. Matrix Biology 15(8-9): 545-554.

Brunette, D. M., \& Till, J. E. 1971. A rapid method for the isolation of L-cell surface membranes using an aqueous two-phase polymer system. The Journal of Membrane Biology 5(3): 215224.

Cao, H., \& Xu, S. Y. 2008. Purification and characterization of type II collagen from chick sternal cartilage. Food Chemistry 108(2): 439-445.

Cheang, B., \& Zydney, A. L. 2004. A two-stage ultrafiltration process for fractionation of whey protein isolate. Journal of Membrane Science 231(1-2): 159-167.

Chrom, A., Dobell, R. A. H., \& Roche, H. E. R. 1987. New metal chelate adsorbent selective and peptides containing neighbouring histidine residues. Journal of Chromatography 411: 177-184

Cliche, S., Amiot, J., Avezard, C., \& Gariépy, C. 2003. Extraction and characterization of collagen with or without telopeptides from chicken skin. Poultry Science 82(3): 503 509.

Coskun, O. 2016. Separation Tecniques: Chromatography. Northern Clinics of Istanbul 3(2): 156-160.

Creighton, T. E. 1989. Protein structure: A practical approach. Oxford University Press.

Dimitrova, N., Zamudio, J. R., Jong, R. M., Soukup, D., Resnick, R., Sarma, K., Ward, A. J., Raj, A., Lee, J., Sharp, P. A., \& Jacks, T. 2017. A Unified Method for Purification of Basic Proteins. PLOS ONE 32(7): 736-740.

Eriksson, A., Burcharth, J., \& Rosenberg, J. 2013. Animal derived products may conflict with religious patients ' beliefs. $B M C$ Medical Ethics 14(48): 1-5.

Felician, F. F., Xia, C., Qi, W., \& Xu, H. 2018. Collagen from marine biological sources and medical collagen from marine biological sources and medical applications. Chem. Biodiversity 15(e1700557): 1-18.

Fidler, A. L., Boudko, S. P., Rokas, A., \& Hudson, B. G. 2018. The triple helix of collagens - An ancient protein structure that enabled animal multicellularity and tissue evolution. Journal of Cell Science 131(7): 1-15.

Fujita-Yamaguchi, Y. (2015). Affinity chromatography of native and recombinant proteins from receptors for insulin and IGF-I to recombinant single chain antibodies. Frontiers in Endocrinology 6(166): 1-5.

Ghosh, R., \& Gui, Z. F. 2000. Purification of lysozyme using ultrafiltration. Biotechnology and Bioengineering 68(2): 191-203.

Glatz, C. E. 2009. Purification and characterization of a transgenic corn grain-derived recombinant collagen type I alpha 1. Biotechnology Progress 25(6): 1660-1668.

Gorres, K. L., \& Raines, R. T. 2010. Prolyl 4-hydroxylase. Informa Healthcare 45(2): 106-124.

Grilo, A. L., Aires-barros, M. R., \& Azevedo, A. M. 2014. Partitioning in aqueous two-phase systems : fundamentals, applications and partitioning in aqueous two-phase systems : fundamentals, applications and trends. Separation \& Purification Reviews 45(1): 68-80

Hashim, P., Mohd Ridzwan, M. S., Bakar, J., \& Mat Hashim, D. 2015. Collagen in food and beverage industries. International Food Research Journal 22(1): 1-8.
Hatti-Kaul, R. 2000. Aqueous Two Phase System Methods in Biotechnology. Sweden. Humana Press.

Herbert, E., Steinemann, T. L., Lehman, E., Thompson, H. W., Varnell, E. D., Jacob-labarre, J. T., \& Gebhardt, B. M. 1994. Collagen-based drug delivery and artificial tears. Journal of Ocular Pharmacology 10(1): 17-27.

Iqbal, M., Tao, Y., Xie, S., Zhu, Y., Chen, D., Wang, X., Huang, L., Peng, D., Sattar, A., Abu, M., Shabbir, B., Hussain, H. I., Ahmed, S., \& Yuan, Z. 2016. Aqueous two-phase system (ATPS): an overview and advances in its applications. Biological Procedures Online 18(1): 1-18.

Jankowski, T. 2012. Determination of phase diagrams and thermoseparation behaviourof aqueous two-phase systems composed of ethylene oxide-propylene oxide random copolymer and potassium phosphate. Chemical and Process Engineering 33(3): 411-429.

Jiang, F., Gao, C., Shen, J., Li, D., \& Qiu, J. 2009. Purification and concentration of collagen by charged ultrafiltration membrane of hydrophilic polyacrylonitrile blend. Separation and Purification Technology 66(2): 257-262.

Johansson, H.-O., Feitosa, E., \& Junior, A. P. 2011. Phase diagrams of the aqueous two-phase systems of poly(ethylene glycol)/sodium polyacrylate/salts. Polymers 3(1): 587-601.

Jongjareonrak, A., Benjakul, S., Visessanguan, W., \& Tanaka, M. 2005. Isolation and characterization of collagen from bigeye snapper (Priacanthus macracanthus) skin. Journal of the Science of Food and Agriculture 85: 1203-1210.

Kadler, K. E., Baldock, C., Bella, J., \& Boot-Handford, R. P. 2007. Collagens at a glance. Journal of Cell Science 120(12): 19551958.

Kahn, D. W., Butler, M. D., Cohen, D. L., Gordon, M., Kahn, J. W., \& Winkler, M. E. 2000. Purification of plasmid DNA by tangential flow filtration. Biotechnology and Bioengineering 69(1): 101-106.

Kaufman, H. E., Steinemann, T. L., Lehman, E., Thompson, H. W., Varnell, E. D., Jacob-LaBarre, J. T., \& Gebhardt, B. M. 1994. Collagen-based drug delivery and artificial tears. Journal of Ocular Pharmacology 10(1): 17-27.

Kiew, P. L., \& Don, M. M. 2013. Modified Lowry's method for acid and pepsin soluble collagen. Open Access Scientifics Reports 2(3): 1-5.

Kittiphattanabawon, P., Nalinanon, S., Benjakul, S., \& Kishimura, H. 2015. Characteristics of pepsin-solubilised collagen from the skin of Splendid Squid (Loligo formosana). Journal of Chemistry 2015: 1-8.

Krishnan, S., \& Perumal, P. 2013. Preparation and biomedical characterization of jellyfish (Chrysaora quinquecirrha) collagen from southeast coast of India. International Journal of Pharmacy and Pharmaceutical Sciences 5(3): 698-701.

Li, J., Han, W., \& Yu, Y. 2011. Chromatography method. In: Protein Emgineering - Technology and Application (pp. 33-61). Intech.

Lim, Y., Ok, Y., Hwang, S., Kwak, J., \& Yoon, S. 2019. Marine collagen as a promising biomaterial for biomedical applications. Marine Drugs 17(467): 1-32.

Ling, Y. Q., Nie, H. L., Su, S. N., Branford-White, C., \& Zhu, L. M. 2010. Optimization of affinity partitioning conditions of papain in aqueous two-phase system using response surface methodology. Separation and Purification Technology 73(3): 343-348.

Lingala, S. M., \& Ghany, M. G. M. Mhs. 2016. Overview of the Purification of recombinant proteins. Current Protocol in Protein Science 25(3): 289-313.

Liu, Z., Oliveira, A. C. M., \& Su, Y.-C. 2010. Purification and characterization of pepsin-solubilized collagen from skin and connective tissue of giant red sea cucumber (Parastichopus californicus). Journal of Agricultural and Food 
Chemistry 58(2): 1270-1274.

Machado, J. R., Severo, E. E., de Oliveira, J. M. G., Ores, J. da C., Brandelli, A., \& Kalil, S. J. 2018. One-step ultrafiltration process for separation and purification of a keratinolytic protease produced with feather meal. International Journal of Chemical Engineering 2018: 1-7.

Madadlou, A., O'Sullivan, S., \& Sheehan, D. 2004. Fast protein liquid chromatography. In: Protein chromatography: Methods and protocols, methods in molecular biology . pp. 59-76. Springer Science+Business Media.

Magdeldin, S., \& Moser, A. 1996. Affinity chromatography: Principles and applications. In S. Magdeldin. In: Affinity Chromatography. pp. 4-28. Rejika: IntechOpen.

Raman, M., \& Gopakumar, K. 2018. Fish collagen and its applications in food and pharmaceutical industry: a review. EC Nutrition 13(12): 752-767.

Mazzola, P. G., Lopes, A. M., Hasmann, F. A., Jozala, A. F., Penna, T. C. V, Magalhaes, P. O., Rangel-yagui, C. O., \& Jr, A. P. 2008. Liquid - liquid extraction of biomolecules: an overview and update of the main techniques. Journal of Chemical Technology and Biotechnology 83: 143-157.

Muyonga, J. H., Cole, C. G. B., \& Duodu, K. G. 2004. Characterisation of acid soluble collagen from skins of young and adult Nile perch (Lates niloticus). Food Chemistry 85: 81-89.

Peng, Y. Y., Howell, L., Stoichevska, V., Werkmeister, J. A., Dumsday, G. J., \& Ramshaw, J. A. M. 2012a. Towards scalable production of a collagen-like protein from Streptococcus pyogenes for biomedical applications. Microbial Cell Factories 11: 1-8.

Peng, Y. Y., Howell, L., Stoichevska, V., Werkmeister, J. A., Dumsday, G. J., \& Ramshaw, J. A. M. 2012b. Towards scalable production of a collagen-like protein from Streptococcus pyogenes for biomedical applications. Microbial Cell Factories 11(1): 1.

Pontis, H. G. 2017. Protein and carbohydrate separation and purification. In: methods for analysis of carbohydrate metabolism in photosynthetic organisms. pp. 45-63.

Przybycien, T. M., Pujar, N. S., \& Steele, L. M. 2004. Alternative bioseparation operations: Life beyond packed-bed chromatography. Current Opinion in Biotechnology 15(5): 469478.

Radić, N., \& Prkic, A. 2012. Historical remarks on the HendersonHasselbalch equation: Its advantages and limitations and a novel approach for exact $\mathrm{pH}$ calculation in buffer region. Reviews in Analytical Chemistry 31(2): 93-98.

Raja, S., Murty, V. R., Thivaharan, V., \& Rajasekar, V. 2011. Aqueous two phase systems for the recovery of biomolecules - a review. Science and Technology 1(1): 7-16.

Raman, M., \& Mathew, S. 2014. Study of chemical properties and evaluation of collagen in mantle, epidermal connective tissue and tentacle of Indian Squid, Loligo dwvauceli Orbigny. Journal of Food Science and Technology 51(8): 1509-1516.

Ramli, R., Bolong, N., \& Yasser, A. Z. 2014. Review on the factors affecting ultrafiltration hollow fiber membrane operational performance in water treatment. Universiti Malaysia Sabab 1: $1-10$.

Ramshaw, J. A. M., Werkmeister, J. A., \& Dumsday, G. J. 2014. Emerging directions for biomedical materials. Bioengineered 5(4): $227-233$

Ratanapongleka, K. 2013. Recovery of biological products in aqueous two phase systems. International Journal of Chemical Engineering and Applications 1(2): 191-198.

Ricard-Blum, S., \& Ruggiero, F. 2005. The collagen superfamily: From the extracellular matrix to the cell membrane. Pathologie Biologie 53(7): 430-442.

Rito-palomares, M. 2006. Direct comparison between ionexchange chromatography and aqueous two-phase processes for the partial purification of penicillin acylase produced by $E$. coli. Journal of Chromatography B 835: 77-83.

Rito-Palomares, M. 2004. Practical application of aqueous twophase partition to process development for the recovery of biological products. Journal of Chromatography B: Analytical Technologies in the Biomedical and Life Sciences 807(1): 3-11.

Rito-palomares, M., Dale, C., \& Lyddiatt, A. 2014. Aqueous twophase fractionation of biological suspensions for protein recovery from bovine blood. Biotechnology Techniques 12: 711714.

Royhaila, N., Haziqah, N., Marzuki, C., Aziah, N., Huyop, F., \& Wahab, R. A. 2015. Review; agriculture and environmental biotechnology an overview of technologies for immobilization of enzymes and surface analysis techniques for immobilized enzymes. Biotechnology \& Biotechnological Equipment 29(2): 205-220.

Rutschmann, C., Baumann, S., Cabalzar, J., Luther, K. B., \& Hennet, T. 2013. Recombinant expression of hydroxylated human collagen in Escherichia coli. Applied Microbiology and Biotechnology 98(10): 4445-4455.

Sadowska, M., Kołodziejska, I., \& Niecikowska, C. 2003. Isolation of collagen from the skins of Baltic cod (Gadus morbua). Food Chemistry 81(2): 257-262.

Sarubbo, L. A., De Oliveira, L. A., Figueiredo Porto, A. L., De Campos-Takaki, G. M., \& Tambourgi, E. B. 2004. Partition of proteins in aqueous two-phase systems based on cashewnut tree gum and poly(ethylene glycol). Brazilian Arcbives of Biology and Technology 47(5): 685-691.

Sato, K., Tanahashi-Shiina, T., Jun, F., Watanabe-Kawamura, A., Ichinomiya, M., Minegishi, Y., Tsukamasa, Y., Nakamura, Y., Kawabata, M., \& Ohtsuki, K. 2003. Simple and rapid chromatographic purification of type $\mathrm{V}$ collagen from a pepsin digest of porcine intestinal connective tissue, an unmanageable starting material for conventional column chromatography. Journal of Chromatography B: Analytical Technologies in the Biomedical and Life Sciences 790(1-2): 277283.

Senaratne, L. S., Park, P. J., \& Kim, S. K. 2006. Isolation and characterization of collagen from brown backed toadfish (Lagocephalus gloveri) skin. Bioresource Technology 97(2): 191 197.

Shin, S., Ikram, M., Subhan, F., Kang, H. Y., Lim, Y., Lee, R., Jin, S., Jeong, Y. H., Kwak, J., Na, Y., \& Yoon, S. 2016. Alginate/marine collagen/agarose composite hydrogels as matrices for biomimetic 3D cell spheroid formation Suil. RSC Advances 6(52): 46952-46965.

Shon, H. K., Vigneswaran, S., K, J., \& Asamy. 2011. Membrane technology for organic removal in wastewater. In: water and wastewater treatment technologies - Membrane technology for organic removal in wastewater. Encyclopedia of Life Support System (EOLSS).

Silva, D. F. C., Azevedo, A. M., Fernandes, P., Chu, V., Conde, J. P., \& Aires-Barros, M. R. 2014. Determination of aqueous two phase system binodal curves using a microfluidic device. Journal of Chromatography A 1370: 115-120.

Silva, T. H., Moreira-Silva, J., Marques, A. L. P., Domingues, A., Bayon, Y., \& Reis, R. L. 2014. Marine origin collagens and its potential applications. Marine Drugs 12(12): 5881-5901.

Silvipriya, K. S., Kumar, K. K., Bhat, A. R., Kumar, B. D., \& John, A. 2015. Collagen: animal sources and biomedical application. Journal of Applied Pharmacentical Science 5(03): 123-127.

Singh, P., Benjakul, S., Maqsood, S., \& Kishimura, H. 2011. Isolation and characterisation of collagen extracted from the skin of striped catfish (Pangasianodon hypophthalmus). Food Chemistry 124(1): 97-105.

Singh, S., \& Tavana, H. 2018. Collagen partition in polymeric aqueous two-phase systems for tissue engineering. Frontiers 
in Chemistry 6(September): 4-10.

Smith, M. C., Furman, T. C., \& Ingoliaq, T. D. 1988. Chelating peptide-immobilized metal ion affinity chromatography. The Journal of Biological Chemistry 263: 7211-7215.

Song, Y., Sauret, A., \& Shum, H. C. 2013. All-aqueous multiphase microfluidics. Biomicrofluidics 7(6): 1-12.

Souza, D. R. D. 2016. Extraction of collagen from fish wastes, optimization and characterization. IOSR Journal of Economics and Finance 3(1): 56.

Stitt, E. H., \& Weatherley, L. R. 1994. Aqueous two-phase extraction systems. In: Engineering Processes for Bioseparations. pp. 202-232.

Swatschek, D., Schatton, W., Kellermann, J., Müller, W. E. G., \& Kreuter, J. 2002. Marine sponge collagen: Isolation, characterization and effects on the skin parameters surface$\mathrm{pH}$, moisture and sebum. European Journal of Pharmaceutics and Biopharmaceutics 53(1): 107-113.

Tang, C. Y., Chong, T. H., \& Fane, A. G. 2011. Colloidal interactions and fouling of $\mathrm{NF}$ and $\mathrm{RO}$ membranes: $\mathrm{A}$ review. Advances in Colloid and Interface Science 164(1-2): 126143.

Tangvarasittichai, S., Tangvarasittichai, O., \& Jermnim, N. 2009. Comparison of fast protein liquid chromatography (FPLC) with HPLC, electrophoresis \& microcolumn chromatography techniques for the diagnosis of $\beta$ thalassaemia. Indian Journal of Medical Research 242-248.

Tianwei, T., Qing, H., \& Qiang, L. 2002. Purification of glycyrrhizin from Glycyrrbiza uralensis Fisch with ethanol/phosphate aqueous two phase system. Biotechnology Letters 24(17): 1417-1420.

Tjerneld, F., \& Albertsson, P. 1994. Phase Diagram. In: Methods in Enzymology, 228: 3-13.

Urh, M., Simpson, D., \& Zhao, K. 2009. Affinity chromatography : general methods. In: Methods in enzymology. Elsevier Inc.

Van Reis, R., \& Zydney, A. 2007. Erratum to bioprocess membrane technology. Journal of Membrane Science 302(1-2): 271.

Wang, T., Lew, J., Premkumar, J., Poh, C. L., \& Win Naing, M. 2017. Production of recombinant collagen: state of the art and challenges. Engineering Biology 1(1): 18-23.

Warner, L. R., Blasick, C. M., Brown, R. J., \& Oxford, J. T. 2007. Expression, purification, and refolding of recombinant collagen $\alpha 1(\mathrm{XI})$ amino terminal domain splice variants. Protein Expression and Purification 52(2): 403-409.

Werkmeister, A., \& Ramshaw, J. A. M. 2015. A simple cost efective methodology for large scale purification of recombinant non-animal collagens. Applied Microbiology and Biotechnology 98(4): 1807-1815.

Xing, J., Fan, D., Xue, W., Zhu, C., Ma, X., \& Ma, R. 2012. A Purification process based on self-assembly for recombinant human-like collagen. Chemical Engineering Communications 199(6): 710-719.

Xu, C., Yu, Z., Inouye, M., Brodsky, B., \& Mirochnitchenko, O. 2010. Expanding the family of collagen proteins : recombinant bacterial collagens of varying composition form triple-helices of similar stability. Biomacromolecules 11: 348-356.

Xu, C., Yu, Z., Inouye, M., Brodsky, B., \& Mirochnitchenko, O. 2014. Bacterial collagen-like proteins that form triple-helical structures. Journal of Structural Biology 186(3): 451-461.

Xu, Y., Keene, D. R., Bujnicki, J. M., Höök, M., \& Lukomski, S. 2002. Streptococcal Scl1 and Scl2 proteins form collagenlike triple helices. Journal of Biological Chemistry 277(30): 27312-27318.

Yamazaki, C. M., Kadoya, Y., Hozumi, K., Okano-kosugi, H., Asada, S., Kitagawa, K., Nomizu, M., \& Koide, T. 2010. Biomaterials A collagen-mimetic triple helical supramolecule that evokes integrin-dependent cell responses. Biomaterials 31(7): 1925-1934.

Yd, S., Em, A., Yusoff, A., Ssa, H., Ty, N., \& Mys, A. 2013. Extraction, purification and physical characterization of collagen from body wall of sea cucumber bohadschia bivitatta. Health and the Environmental Journal 4(2): 53-65.

Zhang, C., Baez, J., \& Glatz, C. E. 2009. Purification and characterization of a $44-\mathrm{kDa}$ recombinant collagen I alpha 1 fragment from corn grain. Journal of Agricultural and Food Chemistry 57(3): 880-887.

Zucca, P., Fernandez-lafuente, R., \& Sanjust, E. 2016. Agarose and its derivatives as supports for enzyme immobilization. Molecules 21: 1-25. 